\title{
Improving Speaking Skill Through Joyful, Active, Creative, Effective Approach (JACEA): Classroom Action Research at Fourth Grade Student
}

\author{
Noldy Pelenkahu, ${ }^{1, *}$ \\ ${ }^{1}$ English Department, Manado State University, Indonesia \\ *Correspondence: English Department, Manado State University, Indonesia. Tel: 852-1855-5568. E-mail: \\ noldypelenkahu@ymail.com
}

Received: November 2, 2017

Accepted: November 28, 2017 Online Published: December 27, 2017

doi:10.5430/wjel.v7n4p31

URL: https://doi.org/10.5430/wjel.v7n4p31

\begin{abstract}
This research aims to obtain empirical data regarding to JACEA implementation in improving fourth grade student speaking skill. The two CAR cycles designed in this research. The result showed that in the CAR first cycle there was only $56.50 \%$ students improved their speaking skill, and then in the second cycle it was improve to $91.30 \%$. The sheet monitor described that the JACEA implementing in cycle one reached $82 \%$ and in the second cycle reached 98\%. This means that the JACEA implementing can improve student English speaking skill. The research implicated that JACEA should be used as an English learning approach to improve four grade student speaking skill.
\end{abstract}

Keywords: speaking skill; JACEA; CAR

\section{Rationale}

There are many acts of English instruction still puts as the remembering subject matter in Indonesia today. These instructional acts have to reject, because of English is a mean of global and intellectual communication which being the bridge to process social relationship among people. English is not a dead material, it must be applied in verbal communication process, beside written interaction.

Indonesian government put English as one of subject matter which should be taught and learned started from elementary school, secondary school, middle school, and high education (university). This means to improve educational quality in Indonesia. And to implement English instruction in elementary school had been introduced and stated in the government policy of local content subject matter. Learning English is not only about vocabulary mastery or translating words from Indonesian to English or from English to Indonesian, but more than that English has to apply for verbal communication process until to written process.

There are seven points make speaking is difficult to learn and there are still many teachers considered that English is not important to learn. They did not practice speaking skill to students and only to discuss minimum vocabulary and to translate them into Indonesian. They of course must use learning source and learning media maximally. They do not implement various teaching acts for developing students speaking skill. There are still teachers who do not mastering English well, so they cannot communicate verbally in English. Limitation time makes the development of speaking skill is not maximal. And then the students have minimum interest to mastery conversation in English.

These factors are not being serious difficulties if the teachers have empathy to improve students speaking skill qualifiedly. They can solve them by implementing strategies, methods, or approaches which can develop the students interest and belief for develop their ability to mastering English. If the teachers do not yet mastery the English, the school should facilitate them in the way to give practice and training in order they can do instruction optimally to improve student speaking skill. Low of student motivation in learning English can be if they think that English is a difficult subject matter. They also still have low confidence to speak English. They have less vocabulary for speaking and always do not have good understanding in doing interaction in English. They also tend to be afraid because of they do not have enough knowledge of English grammatical and vocabulary in good condition. They have not able to comprehend what are speaking. 
Another reason is the instructional activities used still less interesting because of the teacher implemented lecture method and more dominate by doing question and answer about the reading content. Vocabulary practice did without explore student speaking skill in English. Otherwise, teachers play important role in developing student speaking skill. There are many strategies, methods, and approaches which can be implemented to make student mastery speaking skill. For instance, joyful, active, creative, and effective approach (JACEA). It is considered that this approach can implement to improve student speaking skill. By implementing this JACEA, it hoped student paradigm of English is difficult to learn can be solve and they can say "I am a great English speaker."

\subsection{Problem Statement}

The main problem of this research is described in the following details statements: (1) there are many students considered English is being difficult and bored subject matter; (2) the student faced big gap in doing communication in English; (3) the student have less interest in learning English because of the instructional process is monotone; (4) the teachers less using learning sources, instructional media, not interesting instructional activities which can help students develop their speaking skill; (5) can implementing joyful, active, creative and effective approach (JACEA) improve student speaking skill?; and (6) how to improve student speaking skill through implementing joyful, active, creative and effective approach (JACEA)?

\subsection{Significant of the Study}

The research is hoped useful for teachers, students, the school, and other educational institution. For the teachers, the approach can be reference or input to prepare for improving student speaking skill. It also helps teachers to solve student capacity in using English in order to make students enjoy to learn English. And it can motivate teachers to make reflection and introspection to get instructional activities or approach which will be more variety and effective. For the students, they can be more active, creative and brave to develop their speaking skill without feeling afraid and not confidence. It can motivate student to be more interest of using English in ease and joyful or fun. To help students to be confidence children in using English well. For the school and other educational institution, it can improve the school image and prestige in English subject matter. To give more information in instructional process of how to improve student speaking skill. And then, it can make new confidence nation generation of English.

\section{Literature Review}

\subsection{English Position in Indonesian Elementary School}

English is a foreign language in Indonesia. It is an international language which is called world communication mean. In this globalization era, many elementary schools had used bilingual learning. And because of English is very useful, English had been put in the Indonesia educational system and it was putting in the education curriculum started from grade one. The government means to put English in the educational curriculum is to give students competence for doing communication in global community. But, there are still many teachers not yet reflect this government objection for developing student potentiality to be mastery in speaking English.

The ability to communicate consists of listening, speaking, reading and writing. Speaking is being the important skill for communication. Through speaking one can present phrases and can directly present ideas verbally. Richards (2002, p. 213) stated that speaking is one of the central elements of communication. That is why, teaching English to the elementary school students needs to develop and to introduce primarily in order they can get the skill well. Interesting teaching materials is being apart in developing student speaking skill.

The teacher ability to manage a class and to make effective instructional strategy asses can help student understand the concepts that English learning not be bore subject matter. So, English education is needed by students for participating and adapting competition in this modern era. The English education has to develop student skill in communication in order they can understand the features of communication of the around community culture.

There are some objectives of English education in elementary school. They are to develop communication ability verbally and written. To improve understanding of the important nature of English as one of the second language for learning mean, to develop understanding about culture and language relationship in order the students can have understanding of cross culture and participating in various culture.

From the three objectives of English education above, it is needed the teacher role and student to realize these objective in elementary school level. Good interaction between student and teacher can make competence students. That is why, teachers have to develop various instructional acts for developing student interest of mastering English. The teachers must implement effective approach, method, or strategy for making students mastery the English well. 
For instance, they can implement role playing, story-telling, and using instructional media, such as flashcards for introducing vocabulary to use hand puppets and so on. And then, they can also use songs for making student being joyful in learning English. Song consists of a simple conversation which can introduce vocabulary. The other aspect which is very important in teaching English is the physical layout in the classroom beside instructional media. The teacher must be able to manage the class creatively and effectively.

\subsection{Speaking Skill}

Luoma (2004, p.10) stated people use their speech to create an image of themselves to other. This means that people in doing interaction to their environment use speaking skill. Speaking is a mean of communication for presenting ideas or feelings verbally. Through interaction with their environment, they can get and develop vocabulary. One speaks to form self to other in order all people know him/her rightly. This must understand by the teachers. In instructional process, the teacher has to give opportunity to student for developing their speaking skill in communication. He/she responsible to teach how to speak well in social interaction because of speaking is a verbal skill which produce linguistic expression systematically for presenting meaning (http://www.uny.ac.id) retrieved on Monday, 18/12-2017, at $1.00 \mathrm{pm}$.

Speaking is a mean to present object which one wants to reach and to say feeling through expressions in verbal process. One in daily routine has speaking ability to do social contact with others and to develop interaction. Teacher also in doing instruction must have good speaking ability in order students can understand the teaching materials presenting and discussing with others. He/she has to have good speaking skill to say thoughts and ideas for being able to communicate with students and other colligates. Speaking is a skill and such as needs to be develop and practical independently of grammar curriculum (Thornbury in Jodih Rusmajadi, 2010, p. 55). This means that speaking has to develop and practice independently in the object of communication. It is a live skill which has to discuss. It produces thought, request, and ideas which can use in communication.

Ghazali (2010, p. 249) stated that the ability to speak is a thing grow of experience, so one can learn how to interact verbally in the way to participate directly in conversation. In this context, conversation can be the bridge to someone to master speaking skill because of conversation is being one of social interaction. Through conversation one can experience by him/herself of speaking for transferring idea, message, giving input, criticize, and the other. Richards $(2008,22)$ in the context of teaching listening and speaking, stated "when people meet, they exchange greetings, engage in small talk and chit-chat, recount recent experiences and so on because they wish to be a friendly and to establish a comfortable zone of interactions with other. So, through talk or social interaction, one can develop his/her speaking skill. In social interaction, one participates in a talk directly with other. When one meet other, he/she greats and speak and then tell new experience and then hopes he/she can be friend to form a comfort zone in the interaction with other.

From some ideas above, it can be concluded that speaking skill is a language skill to communicate face to face verbally as the mean to share ideas, thoughts, messages, or feelings and experiences. This is relevant with Brown and Yule (1999, p. 27), stated that people should be able to express himself in the target language, to cope basic interactive skills like exchanging greetings and thanks and apologies, and to express his needs-request, information, service, etc. Richards and Rinandya (2002, p. 201) have also the same idea about speaking ability. They stated "We may use speaking is used for many different purposes, and each purpose involves different skills. When we use casual conversation, for example, our purposes may be to make social contact with people and/or to establish rapport. When we engage in discussion with someone, the purpose may be to seek or express opinions, to persuade someone about something, or to clarify information. We may use speaking to describe things, to complains about people's behavior, to make polite request, or to entertain people with jokes and anecdotes.

There some components underlined English speaking effectively. Communication ability or speaking categorized grammatical competence, discourse competence, sociolinguistic competence, and strategic competence (Richards and Rinandya, 2002, p. 207). Grammatical competence is the grammar competence consists of morphology and syntax, vocabulary and its mechanism. So, grammar make speaker to use and understand English structure rightly where he can add speaking English fluently. And then vocabulary can make speaker mastery speaking skill because with vocabulary mastery one can speak well, and so, the mechanism ability basically the letter sound, expressing, until intonation, all use in speaking act. In the context of discourse competence, beside grammatical competence, English learner has to develop discourse competence related to inter sentence. In discourse, evenness inter sentence informal or formally, polite or not implemented with full meaning in social relationship. For instance, in speaking act, the usage of "Good morning" is more good to express for saying hello to greet people or to use "Could I ...." for being polite and formal than to use "Can I ...." And then, in the context of sociolinguistic competence, this refers to 
what knowledge which hoped by the target language user in social context. To understand sociolinguistic in speaking can help one to know what certain ideas to give, how to ask along interaction process, and how one can response verbally suitable with speaking objective itself. Canale and Swain (1980) figured the speaking competence as then following.

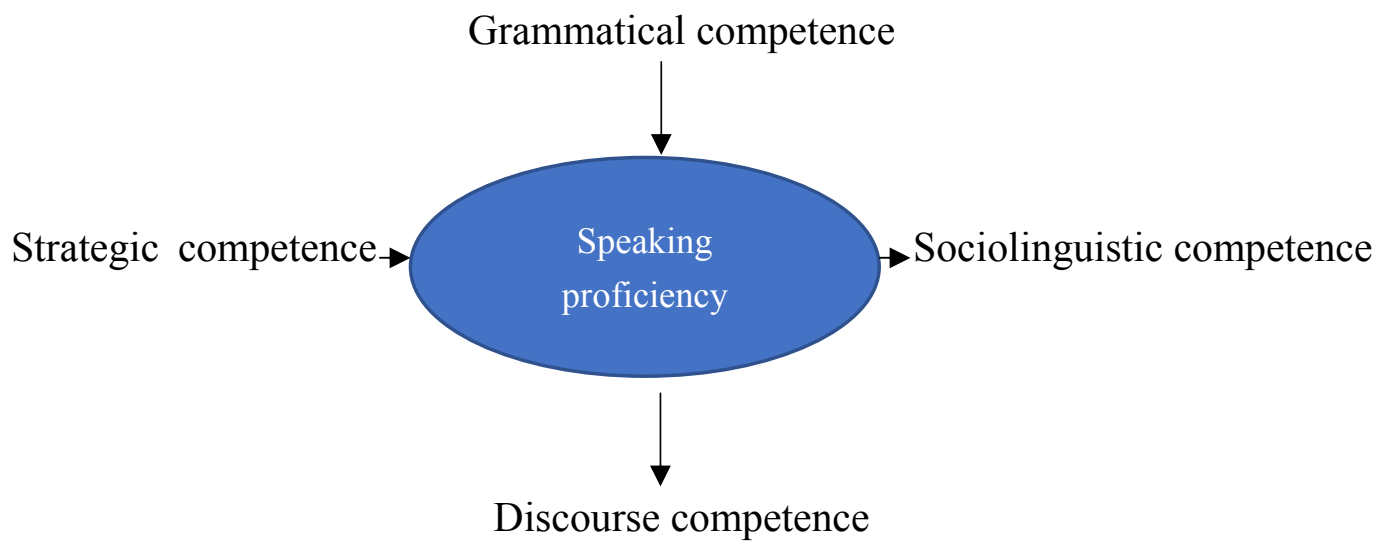

Figure 1. The Abilities Underlying Speaking Proficiency

Today, English has to learn integrated by the students. Listening, speaking, reading and writing must be learn togetherness. Speaking is being the main aspect because if one had been able speak well, so the other three aspects can be developed well. oral communication is a vital component of the English language arts curriculum and provide the base for growth in reading, writing, and listening abilities (http://www.sasked.gov.sk.ca/docs/mla/speak.html) retrieved Monday, 18/12-2017, at $1.20 \mathrm{pm}$. The first message of one can speaking English well is seen on speaking skill not from listening skill or writing skill. So that, to the learners of speaking needs to give specific attention more of speaking skill. The first thing which must be attended by teacher in teaching speaking is to introduce student with vocabulary supporting by instructional media. And the developing acts which are useful to get student potentiality to master speaking skill is doing conversation. Communication in the classroom is embedded in meaning-focused activity. This requires teacher to tailor their instruction carefully to the needs of learners and to teach them how to listen to other, how to talk with others, and how to negotiate meaning in a shared context (Richards and Rinandya, 2002, p. 208). Children learning a foreign language in formal school setting learn best by communicating primary through oral language; effective programes give children early opportunities for practice or routine language and basic language patterns (McKay, 2006, p. 177).

There are six acts support speaking skill improvement in the instruction process. They are acting from a script, communication games, discussion, prepared talks, questionaires, and simulation and role-play. The role-play act used here and managed for joyful, active, creative, and effective approach implementation in the research. Through this act students can directly experience the speaking process and hoped they can improve confidence to produce language verbally for the next knowledge of language. Medwel, et.al. (2009, p. 33) stated "role-play areas can also provide enriching language experiences. One other way of getting students to speak is role-playing. Students pretend they are in various social contexts and have a variety of social roles. In role-play activities, the teacher gives information to the learners such as who they are and what they think or feel (Kayi, 2006, p. 2). Hurlock (1980, pp. 152 and 191) stated that mistaken in speaking on the end of children time lower than their ages before, a new word maybe the first time they can use, speak not rightly but after listen some time the expression rightly, children had been able to speak it rightly. The vital thing is that children can understand that the nucleus of communication is they can understand what can they speak to other people. If children can understand what they can speak to other. It is not they cannot communicate but tend they say something not relevant with what discussed. That is why, students have to be practical their comprehension for doing speaking well in order they can improve speaking skill. In comprehension, teacher needs to concerned about understanding everything in normal educated conversation, except for vey colloquial or low-frequency items or exceptionally rapid or slurred. In communication needs fluency. Teacher needs to focused speech is effortless and smooth, but perceptibly nonnative in speed and evenness.

There are three basic reasons why it is a good idea to give students speaking tasks which provoke them to use all and 
any language at their command. Rehearsal: getting students to have a free discussion give them a chance to rehearse having discussions outside the classroom. Having them take part in a role-play at an airport check-in desk allows them to rehearse such a real-life event in the safety of the classroom. This is not the same as practice in which more detailed study takes place; instead it is a way for students to get the feel of what communicating in the foreign language really feels like. Feedback: speaking tasks where students are trying to use all and any language they know provides feedback for both teacher and students. Teachers can see how well their class is doing and what language problems they are having (that is a good reason for 'boomerang' lessons); students can also see how easy they find a particular kind of speaking and what they need to do to improve. Speaking activities can give them enormous confidence and satisfaction, and with sensitive teacher guidance can encourage them into further study. Engagement: good speaking activities can and should be highly motivating. If all the students are participating fully - and if the teacher has set up the activity properly and can then give sympathetic and useful feedback - they will get tremendous satisfaction from it. Many speaking tasks (role-playing, discussion, problem-solving, etc.) are intrinsically enjoyable in themselves (Harmer, 2002, pp. 87-88).

\subsection{Joyful Learning Approach}

Teachers in elementary school are hoped to motivate students participate actively in teaching and learning process and then to develop their potentialities. Teachers must make students enjoy and active in learning in order they can feel to fulfil the learning need. In this context, teachers have to use joyful learning approach. It is suitable for reaching the learning objectives. The instructional concept is to student center learning and learning is fun. Learning is fun is developed as a game which do not eject the elements of joyful learning. Amri, et. All. (2010, p. 15) stated that learning is fun is the key to apply in innovative instruction. If students had been put this in his/her thought, it will not yet be passive in the class, disturb feeling, not to be success, limitation of alternative and feel bored do not reach by the students.

Joyful learning is an approach which can make students do various activities for developing the attitude, general skill, specific skill, and to comprehend well of the subject matter in the context of doing by learning. Through this approach, student role actively along the instructional process and the teacher facilitate them. All the activities are student centered learning. Teachers can applicate instructional methods for developing student interest in learning and to develop their potentialities (Asmani, 2011, p. 63).

Joyful learning is a concept designed to activate students in developing creativities in a joyful atmosphere. It consists of four pillars (joyful, active, creative, and effective). It is the concept to make students active and joyful in learning. In joyful learning, teacher has to create certain situation in order that student actively raise question, give ideas, creative, critical, and concentrating fully on learning (Seameo Regional Center, 2012, pp. 5 and 33). So, there are seven tips in joyful learning, they are to evaluate individual ability through certain tasks, determining the instructional needs, help and motivate students, help and motivate teachers for teaching well, determining instructional strategies, the institution accountability, and improving the educational quality (Asmani, 2011, pp. 106-107).

Joyful learning process has the characteristics as the following: there is source of various learning and do not depend on textbook as the learning source. This is done in order to richly student experiences and the source of learning. The scenario is designed by many activities and usually dominate by individual act, and the groups for doing tasks. Students individually and in groups try to develop maximally their creativities until they can get enthusiasm and feel joy and fun in the end of the instructional process, the last they can reflect themselves (Suparlan, 2009, pp. 70-71).

\subsection{Active Learning Approach}

Active learning is not only for fun and game, it is about making students face challenges which they must work hard. It is about thought of activities when they do and discuss the value of them. It consists of various suggestions for helping student reflects what which they had been experienced. It needs not more time to make students know what they are learning. Lay-out of class is important to make students active in learning. U lay-out class is ideal for distribute teaching materials to students quickly because teacher can walk to anywhere in the class. Team characteristic can make teacher can interact to student team. Conference table can form formal feeling if the teacher is at the corner. Cycle makes students interact face-to-face directly. Workstation/active laboratory can make students operate easily the teaching media used in learning. Breakout grouping is making students learning activity in the team. These all classroom management makes students active in learning (Silberman, 1996, pp. 14-19). Active learning approach was evaluated can make creating excitement in the classroom, getting students to think and work, student must do more than just listen, they must read, write, discuss, or be engaged in solving problems, and higher order thinking (Budimansyah, Suparlan, and Meirawan, 2009). 
Harmin and Toth (2006, p. 320), stated that sometimes you might alert and actively involved in a lesson, doing the very best you can. You are then high up on this thermometer, up here, at 4. Believe it or not, sometimes students are not at all active. Maybe they are feeling a little sick, or tired, or distracted, or upset. At in time they would be down here, at 1 . And sometimes students are in between. We might say they are usually alert and active, up about here, at 3 . Or they might be sometimes active and alert, down about here, at 2 . The following figure is the active learning thermometer.

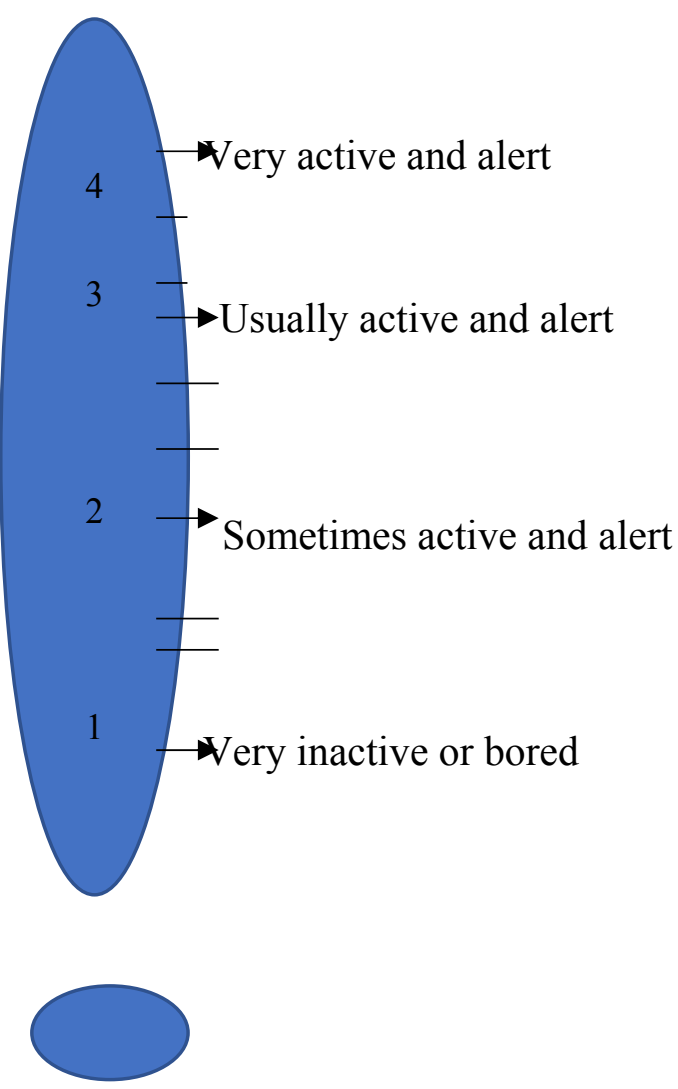

Figure 2. Active Learning Thermometer

When learning is active, students do most of the work. They use brains studying ideas, solving problems, and applying what they learn. Active learning is fast-paced, fun, supportive, and personally engaging, often students are out of their seats, moving about and thinking aloud. To learn something well, it helps to hear it, see it, ask questions about it, and discuss it with others. Above all, students need to "do it" - figure things out by themselves, come up with examples, try out skills, and do assignments that depend on the knowledge they already have or must acquire. Active learning brings together in one source a comprehensive collection of instructional strategies. It includes ways to get students active from the start through activities that build teamwork and immediately get them thinking about the subject matter. There are also techniques for conducting full-class learning and small-group learning, stimulating discussion and debate, practicing skills, prompting questions, and even getting the students to teach each other. Finally, there are methods for reviewing what's been learned, assessing how one has changed, and considering the next steps to take so that the learning sticks. Active learning is for anyone, experienced or novice, who teaches technical or nontechnical information, concepts, and skills. The techniques are designed to do one or more of the following: team building (helping students to become acquainted with each other or creating a spirit of cooperation and interdependence), on-the-spot assessments (learning about students' attitudes, knowledge, and experience of students), and immediate learning involvement (creating initial interest in the subject matter (Silberman, 1996, pp.ix-xi).

\subsection{Creative Learning Approach}

There are four ideas that challenge conventional views about creativity. First, creativity is important in everyday creativities. Most of us associate the creative process with the development of great works of arts and music, or 
perhaps with a clever new invention. Creativity is as a part of our daily work and leisure lives. It is designed to increase problem-solving capacity, creative expression, empathy, and insight into social relations. The meaning of ideas can be enhanced through creative activity by helping us see things more richly. Second, the creative process is not at all mysterious. It can be described, and it is possible to trains persons directly to increase their creativity. Creativity is viewed as a mysterious, innate, and personal capacity that can be destroyed if its processes are probed too deeply. If individual understand the basis of the creative process, they can learn to use that understanding to increase the creativity with which they live and work, independently and as members of groups. Don't view that creativity if enhanced by conscious analysis led him to describe it and create training procedures that can be applied in schools and other setting. Third, creative invention is similar in all fields-the arts, the sciences, engineering and is characterized by the same underlying intellectual processes (Joyce and Weil, 1996, pp. 239-240).

\subsection{Effective Learning Approach}

There are five behaviors considered essential for effective teaching, they are lesson clarity, instructional variety, teacher task orientation, engagement in the learning process, and student success rate. Lesson clarity/teacher clarity is that teachers vary considerably on this behavior. Not all teachers are able to communicate clearly and directly to their students without wondering, speaking above student's levels of comprehension, or using speech patterns that impair the clarity of what is being presented. Instructional variety refers to the variability or flexibility of delivery during the presentation of a lesson. One of the most effective ways of creating variety during instruction is to ask questions. Teacher task orientation refers to how much classroom time the teacher devotes to the task of teaching an academic subject. The more time dedicated to the task of teaching a specific topic, the greater the opportunity students have to learn. Some task-related questions a teacher must answer are: (1) how much time do I spend lecturing, asking questions, and encouraging students to inquire or think independently? (2) how much time do I spend organizing for teaching and getting my students ready to learn? And (3) how much time do I spend assessing my learner's performance? Engagement in the learning process refers to the amount of learning time devoted to an academic subject. Student success rate refers to the rate at which students understand and correctly complete exercises (Borich, 1996, pp. 10-24).

Some helping behaviors related to effective teaching are using student ideas and contributions, structuring, questioning, probing, and teacher affect. Use of student ideas and contributions includes acknowledgement, modifying, applying, comparing, and summarizing student responses to promote the goals of a lesson and to encourage student participation. Acknowledging: using the student's idea by repeating the nouns and logical connectives expressed by him or her to increase lesson clarity. Modifying: using the student's idea by rephrasing it or conceptualizing it in your words or another student's words to increase instructional variety. Applying: using the student's idea to teach an inference or take the next step in a logical analysis of a problem to increase success rate. Comparing: taking a student's idea and drawing a relationship between it and ideas expressed earlier by the student to encourage engagement in the learning process. Summarizing: using what was said by an individual student or a group of students as a recapitulation or review of concepts taught to enhance task orientation.

Structuring is the teacher comments which made for the purposes of organizing what is to come, or summarizing what has gone before. Used prior to an instructional activity or question, structuring can serve as an organizer for students, aiding their understanding and retention of the materials to be taught. Used at the conclusion of an instructional activity or question, structuring reinforces learned content and places it in proper relation to other content already taught. Questioning is another important helping behavior. Content questions: teachers pose content questions to have the student deal directly with the content taught. The various terms concerning this are direct: question requires no interpretation or alternative meanings. Lower-order: question requires the recall only of readily available facts, as opposed to generalizations and inferences. Convergent: different data sources lead to the same answer. Closed: question has no possible alternative answers or interpretation. Fact: question requires the recall only of discrete pieces of well-accepted knowledge. Probing refers to teacher statements that encourage students to elaborate upon an answer, either their own or another student's. probing may take the form of a general question or can include other expressions that elicit clarification of an answer, solicit additional information about a response, or redirect a student's response in a more fruitful direction. Probing often is used to shift a discussion to some higher thought level. Teacher affect: anyone who has ever been in a classroom where the teacher's presentation was lifeless, static, and without vocal variety can appreciate the commonsense value of effecting behaviors. Enthusiasm is an important aspect of a teacher's affect. It is related to student achievement and is believed to be important in promoting student engagement in the learning process. Teachers convey enthusiasm to students in many vocal inflections, gestures, eye contact, and animation (Borich, 1996, pp. 24-33). The following are the principles of effective learning approach: delivered contingently, specifies the particulars of the accomplishment, shows 
spontaneity, variety, and other signs of credibility; suggests clear attention to the student's accomplishment, rewards attainment of specified performance criteria which can include effort criteria, however, provides information to students about their competence or the value of their accomplishments, orients students toward better appreciation of their own task-related behaviors and thinking about problem solving (Kindsvatter, Wilen, and Ishler, 1996, p. 59).

Teaching requires a large repertoire of skills and ability to put these skills to use in different situations. Good teachers improvise: No one approach works equally well all the time and in all situations. In short, effectiveness depends on the subject, students, and environmental conditions. So that, effective teaching is complicated. The better teachers, however, are proactive; that is, they are active information processors and decision makers. They are strongly committed to the importance of content delivery and tend to be task-oriented. They understand the demands of teaching their content, the characteristics of their students, and the importance of decision making in keeping students on task. Teacher knowledge of subject matter, student learning, and teaching methods are important elements of effective teaching (Moore, 2005, p. 6).

Joyful, active, creative, and effective learning approach (JACEA) applies various instructional acts and using instructional media optimally in presenting the teaching materials. Classroom organization is being a supportive factor to get successful teaching and learning process. The principle of learning to do guiding students to say ideas and feelings. The following table describes the phases of JACEA.

Table 1. JACEA Instructional Process Phases

\begin{tabular}{ll}
\hline Implementation Phases & Instructional Implementation \\
\hline Pre-activity & Greetings \\
Apperception or scaffolding (this aims to develop student attention \\
and to get their schemata) which is presented through questions \\
Presenting learning objectives orally and in written \\
Teacher divides students in groups of five \\
Teacher give alternative of choosing group \\
Teacher give tasks or problems for discussing in groups \\
Teacher presents regularities applies in groups \\
Teacher give time allotment for doing the tasks \\
Teacher give guidance about the output achieve and the \\
competences reach \\
Teacher invites groups to read the discussion achievement report \\
Teacher give informant towards the discussion achievement report \\
Teacher and students evaluate the instructional process and the \\
instructional achievement implemented. It can be the weaknesses \\
or strengths of the instructional process implemented \\
\hline
\end{tabular}

\subsection{The Action Plan Concept Development and the Action Hypothesis}

This research used JACEA for improving students speaking skills. It implemented two classroom action research cycles. The action steps are planning, action-observation, reflection, and observation. Based on the theoretical and the research framework, the hypothesis of this research is "There is significant effect of JACEA towards speaking skill in English instructional of fourth grade elementary school students."

\section{Research Methodology}

\subsection{The Research Objection and Action Intervention Design}

This classroom action research (CAR) aims to investigate the implementation of JACEA in improving fourth grade student speaking skill. CAR means an empirical research activity which rationally implemented, systematically and empirically reflected towards various actions used by teacher, collaborative (researcher-team) is being the researcher 
start from planning until the evaluation of real action in the class for improving the instructional condition. CAR is implemented in order to correct and improve the instructional process qualitatively and quantitatively which is in the end of the instructional process faced problems in it. The research procedure of this CAR is cycle model as the following.

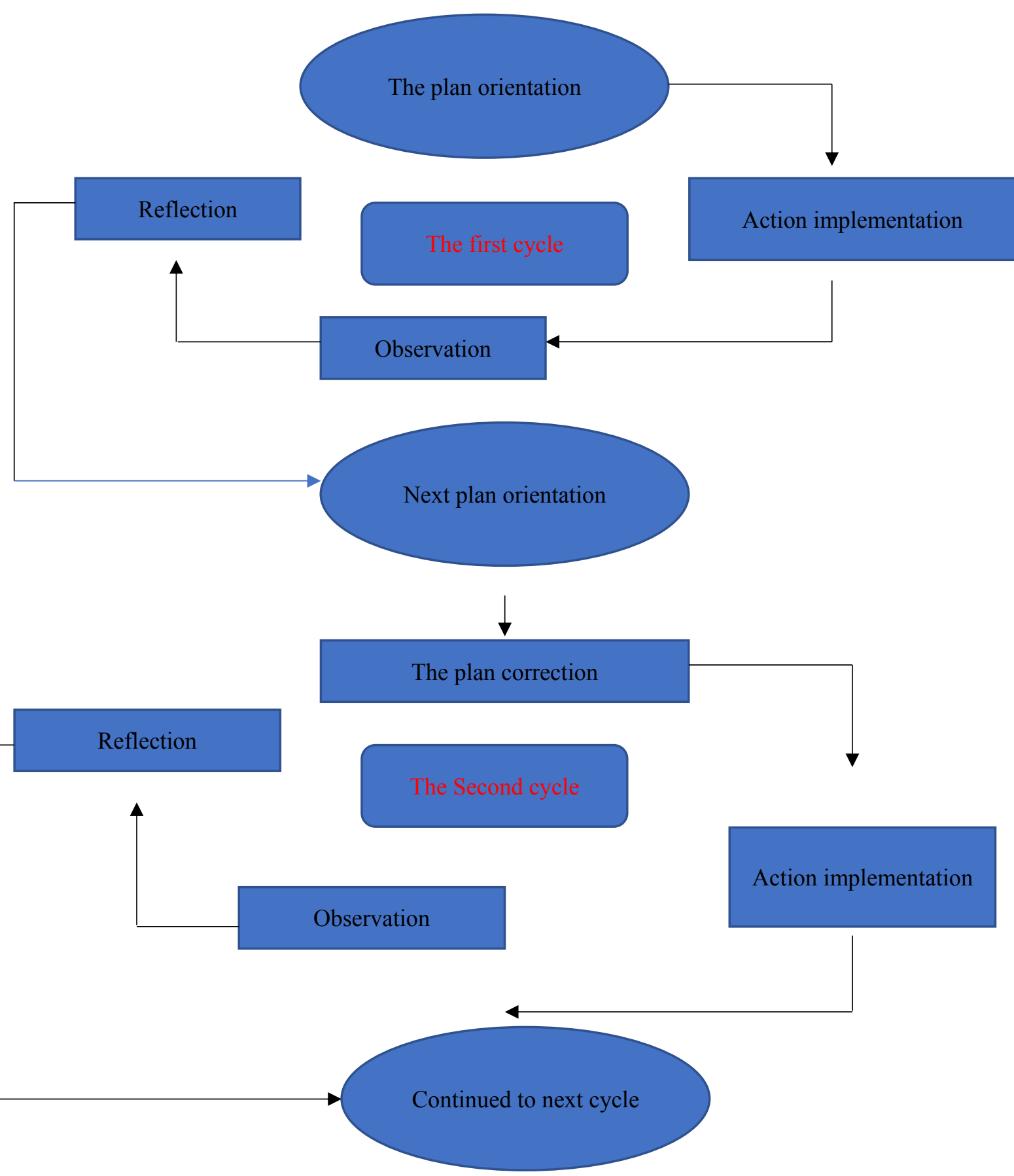

Figure 3. CAR Cycle Model Modification from Kemmis and McTargart Model

\subsection{Action Intervention Phases}

This CAR implemented based on cycle of each phase, that is action plan, action implementation, action observation, and action reflection. Action plan consists of general plan and the specific plan organizes in each cycle. The whole 
plan organized according to discussion between researcher and collaborator. Action implementation is a realization of an action which had been planned before. The speaking skill instruction is applied with JACEA. The implementation is going into two times and each time has two times allotment ( $35 \times 2=70$ minutes). Action observation is done together with collaborator and each collaborator observed the instructional activities started from the early act, implementation process, and the instructional achievement. In this CAR cycle, the observer watched the suitable action with the plan. The observation result is written to field notes based on the collaborator directly and completed by document. Reflection action is done after doing instructional process and then discuses with collaborator about what had happened along the instruction process and then write them in field note. The researcher and collaborator make conclusion of what are achieved by students for making correction to the next action cycle. Reflection action is an evaluation which will be used to determine the plan action in next CAR cycle.

\subsection{The Action Intervention Result Hoped, Data Source, and Competence Base}

The action intervention result hoped in this CAR is there is improving student speaking skill. Criteria of the CAR uses the learning compulsory principle of the instructional process implemented by teacher achieved $100 \%$. This CAR is categorized successful if there are $80 \%$ of students experienced speaking skill improvement suitable with the minimum criterion of $75 \%$. The data collected from instrument consists of teacher action preparation observation sheet with attitude scale. It is used for teacher and student observation of the instructional activities, speaking skill test, field note, and documentation. Class context uses to reach the very simple instruction and information. Competence base consists of speaking for giving and request information in speech acts of request permission, giving permission, acceptance, not agree, rejection, and request clearance description. The following table describes the speaking skill instrument framework.

Table 3. Speaking Skill Instrument Framework

\begin{tabular}{|c|c|c|}
\hline Component & Score & Note \\
\hline \multirow[t]{5}{*}{ Comprehension } & 1 & Don't understand the very simple conversation \\
\hline & 2 & Less understand the conversation so getting problem to speak \\
\hline & 3 & $\begin{array}{l}\text { Enough comprehending the conversation, late of comprehension and needs } \\
\text { repeating }\end{array}$ \\
\hline & 4 & Can comprehend the conversation quickly, but sometime needs repeating \\
\hline & 5 & Very good comprehending the conversation without getting problem \\
\hline \multirow[t]{5}{*}{ Fluency } & 1 & Not fluency to speak, always getting pause in a long time \\
\hline & 2 & $\begin{array}{l}\text { Less fluency to speak and sometime pause because of limitation of } \\
\text { vocabulary }\end{array}$ \\
\hline & 3 & Enough fluency to speak, but still afraid \\
\hline & 4 & Fluency to speak, but sometime needs repeating \\
\hline & 5 & Correctly and very fluency to speak \\
\hline \multirow[t]{5}{*}{ Vocabulary } & 1 & Not uses vocab, so cannot speak \\
\hline & 2 & Less vocabulary mastery, so using limited vocabulary and mistake in usage \\
\hline & 3 & Use enough vocab, but sometime less suitable in usage \\
\hline & 4 & Correct of using vocab and minim in mistakes \\
\hline & 5 & Clear and correct usage vocab and not getting mistakes \\
\hline \multirow[t]{5}{*}{ Pronunciation } & 1 & There is much mistakes and not clear to spell words \\
\hline & 2 & Less clear to spell words, not consistent to speak, and getting less mistakes \\
\hline & 3 & Clear to speak but needs repeating \\
\hline & 4 & Clear to speak and correct in articulation \\
\hline & 5 & Very clear to speak, understood, and correct in articulation \\
\hline \multirow[t]{5}{*}{ Grammar } & 1 & Not correct in sentence structure, not clear to speak and make much mistakes \\
\hline & 2 & Les correct in speaking the words and sentences so less to understand \\
\hline & 3 & Correct in words and sentences but sometime make mistakes \\
\hline & 4 & Good in words and sentences so can be understood \\
\hline & 5 & Use correct words and sentences like native speaker \\
\hline
\end{tabular}

Notes: $5=$ very good, $4=$ good, $3=$ enough good, $2=$ poor, and $1=$ very poor 
Formula: Value $=$

25

The action observation data is getting from instrument. The following table describes the JACEA action observation instrument framework.

Table 4. JACEA Action Observation Instrument Framework

\begin{tabular}{|c|c|c|c|}
\hline Dimension & Indicator & Item & Sum \\
\hline \multirow{13}{*}{ Teacher } & Joyful & 1,2 & 5 \\
\hline & $\begin{array}{l}\text { 1. Condition students for being brave to try and not } \\
\text { afraid to make mistakes }\end{array}$ & & \\
\hline & 2. Develop enthusiasm to students in learning & 3,4 & \\
\hline & 3. Give positive feedback & 5 & \\
\hline & Active & & \\
\hline & 1. Make a learning act to students & $6,7,8$ & \\
\hline & 2. Give questions & $9,10,11$ & 6 \\
\hline & Creative & & \\
\hline & 1. Develop learning activities & 12,13 & \\
\hline & 2. Make learning media in organizing class & 14 & 3 \\
\hline & Effective & & \\
\hline & 1. Reach the instructional objectives & 15 & \\
\hline & & & 1 \\
\hline \multirow[t]{10}{*}{ Student } & Joyful & $1,2,3$ & 5 \\
\hline & $\begin{array}{l}\text { 1. Students brave to try and not afraid to make } \\
\text { mistakes }\end{array}$ & & \\
\hline & 2. Develop student learning enthusiasm & 4 & \\
\hline & 3. Give feedback & 5 & \\
\hline & Active & & \\
\hline & 1. Implementing good learning activities & 6.7 & 4 \\
\hline & 2. Give answer & 8,9 & \\
\hline & Creative & & \\
\hline & $\begin{array}{l}\text { 1. Use conversation creatively in role-play } \\
\text { Effective }\end{array}$ & $10,11,12,13$ & 3 \\
\hline & 1. Reach the instructional objectives & 14,15 & 2 \\
\hline
\end{tabular}

\subsection{Data Analysis and Result Interpretation}

Data analysis of this CAR is done after the researcher used action implementation and reflection the action. Data analysis consists of instrument result, field notes, and observation result. Data analysis is done for knowing various weaknesses and strengths along the CAR implementation and then the researcher can make correction. Data was collected from speaking skill tasks given to students as the pre-test and post-test of each CAR cycle. Data gathering is analyzed by using comparative descriptive analysis (comparing student activating percentage and the teaching materials comprehension inter cycle. And in order to test the validation and reliability level, the researcher used triangulation technique. Triangulation is a data source which means as comparison of what had been done by the researcher, the expert comment/review and the collegeas. The speaking skill test is analyzed using this formula:

\section{Value sum gathering}

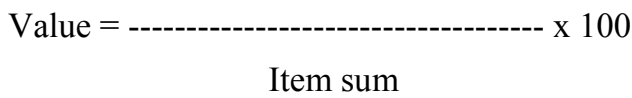


And the reaching percentage of student achievement indicator in a class is counted by using this formula:

Student sum reach achievement indicator

Student achievement Percentage $=$ $\mathrm{x} 100 \%$

Student sum

The research will be ended if $80 \%$ from students had reached the achievement minimum value of 75 . And in order to know the problem caused that the research did not get success is seen from action observation data. It is analyzed using the following formula.

Value gathering sum

Achievement percentage $=$ $\mathrm{x} 100 \%$

Item sum

Interpretation of the research analysis result is done by counting the speaking skill data result implementing JACEA. The achievement percentage is reached from each CAR cycle. And development of action planning can be, if in the first cycle of the CAR is not yet getting improvement in student English speaking skill. In this development of action planning, the instructional activities are more developed by implementing JACEA. Through JACEA, students are given stimulus to more develop the student English speaking skill. Teacher must create learning situation in joyful, active, creative, and effective in order to get the student enthusiasm and being interest to English instruction process because of these can develop their speaking skill. In this instructional process, the researcher and collaborator reflect problems to improve student speaking skill. This means as the researcher guidance in planning the instructional activities in the next CAR cycle in order the same problems and mistakes do not be again.

\section{Result Analysis Interpretation and Discussion}

The CAR which had been implemented to the elementary school fourth grade students started from the first cycle to the second cycle had each characteristic. In this CAR, each process had been the speaking skill improvement and the elementary school fourth grade students English subject matter for each teaching materials of speaking skill was also improved. The following table described the evaluation result and the student learning score target reached.

Table 5. The Evaluation Result and Student Learning Score Target Reached

\begin{tabular}{lcc}
\hline \multicolumn{1}{c}{ Research aspect } & \multicolumn{2}{c}{ Teaching and learning result } \\
\cline { 2 - 3 } & The first CAR cycle & The second CAR cycle \\
\hline Speaking skill mean value & $56.50 \%$ & $91.30 \%$ \\
JACEA implementing effectivity mean score & $82 \%$ & $98 \%$ \\
\hline
\end{tabular}

Based on the above table description, it showed that in the student and teacher activities evaluation of the research data in the second CAR cycle improve to $98 \%$. And the student speaking skill evaluation result reached to $91.30 \%$ with the target criterion reached $82 \%$ and the JACEA implementation effectivity mean score in teaching and learning process reached $98 \%$. This improvement got after implementing two CAR cycles. So that, the data analysis of the research concluded that there was significant improvement of student speaking skill from first CAR cycle to second CAR cycle with the implementation of JACEA, so, this CAR is finished.

\section{Conclusion, Implication, and Suggestion}

\subsection{Conclusion}

According to the data analysis result and the English instructional process using JACEA, it can improve elementary 
school fourth grade students speaking skill. This was showed from there was any improvement from the first CAR cycle to the second cycle. Based on the observation result to the English instructional process using JACEA in first CAR cycle, it got $82 \%$ score of teacher and students teaching and learning activities. This result score improved in the second CAR cycle to $98 \%$. And then, for the speaking skill evaluation result, it was only reached $56.50 \%$. This means that the student achievement of speaking skill is still not getting maximum target of $75 \%$, but in the second CAR cycle, it improved to $91.30 \%$. From the evaluation, it can be concluded that the English instructional process using JACEA can improve the Elementary school fourth grade student speaking skill.

\subsection{Implication}

Based on the above conclusion, this CAR implicated that if the English instructional implementing innovative approach, the teacher applied good classroom management, the teacher has good competence, and using instructional media correctly, it can improve the student mastery and ability to speak English. With the teacher competence in implementing innovative instructional approach through JACEA, it can make students develop their speaking skill well. The JACEA can help students to do good conversation through role-play and then they can feel him/herself the real experience to use language as the mean of communication.

\subsection{Suggestion}

Based on the conclusion and implication of this CAR, it can suggest to the school principle that it hoped seriously he should give supporting maximally to the teachers of making innovative English instructional for teaching speaking skill in order to reach the educational objective nationally in Indonesia. He has to give reward to teacher who succeed to improve the competence achieved in school (especially to the teacher who succeed in implementing update instructional strategy, method, and approach). It is suggested also to educational institution which produced teachers, especially to the lecturer as motivator, facilitator, educational solver problem, and as English subject matter responsible must to follow the development and innovation in English instructional to produce competent teacher to make innovation in educational world.

\section{References}

Amri, et.all. (2010). Proses Pembelajaran Inovatif dan Kreatif dalam Kelas: Metode, Landasan Teoritis-praktis dan penerapannya. Jakarta: Prestasi Pustaka Publisher.

Asmani, Jamal Ma'mur. (2011). 7 Tips Aplikasi Pakem. Jogjakarta: Diva Press.

Borich, Garry D. (1996). Effective Teaching Mathods. New Jersey: Prentice-Hall.

Budimansyah, Dasim, Suparlan, \& Danny Meirawan. (2009). Pembelajaran Aktif, Kreatif, Efektif, dan Menyenangkan. Jakarta: PT Genesindo.

Harmer, Jeremy. (2002). How to Teach English: AIntroduction to the Practice of English Language Teaching. USA: Longman.

Harmin, Merrill \& Melanie Toth. (2006). Inspiring Active Learning: A Complete Handbook for Today's Teachers. USA, Alexandria, Virginia: Association for Supervision and Curriculum Development.

Joyce, Bruce \& Marsha Weil. (1996). Models of Teaching. USA: Allyn \& Bacon, A Simon \& Schuster Company, Needham Heights.

Kindsvatter, Richard, William Wilen \& Margaret Ishler. (1996). Dynamics of Effective Teaching. USA: Longman.

McKay, Penny. (2006). Assessing young learner language. New York: Cambridge University Press.

Medwel, Jane, et.all. (2009). Primary English: Teaching, Theory and Practice. British: British Liobrary Cataloguing in Publication Data.

Moore, Kenneth D. (2005). Effective Instructional Strategy: From Theory to Praxctice. London: Sage Publications.

Richards, Jack C. (2008). Teaching Listening and speaking: From Theory to Practice. Cambridge: Cambridge University Press.

Richards, Jack C., \& Willy A. Renandya. (2002). Methodology Language Teaching. USA: Cambridge University Press. https://doi.org/10.1017/CBO9780511667190

Rusmajadi, Jodih. (2010). Terampil Berbahasa Inggris. Jakarta: PT Index.

Seameo Regional Center. (2012). Modul 2 Active and Joyful Learning. Singapore: Seameo. 
Silberman, Mel. (1996). Active Learning, 101 Active Learning Strategies. USA: Allyn \& Bacon.

Suparlan, (2009). Pembelajaran Aktif, kreatif, Efektif, dan menyenangkan. Bandung: PT Genesindo.

http://www.uny.ac.id Retrieved on Manday 18/12-2017 at $1.00 \mathrm{pm}$.

http://www.sasked.gov.sk.ca/docs/mla/speak.html Retrieved Monday, 18/12-2017, at $1.20 \mathrm{pm}$. 